\title{
Urine Protein Electrophoresis
}

National Cancer Institute

\section{Source}

National Cancer Institute. Urine Protein Electrophoresis. NCI Thesaurus. Code C135568.

An electrophoresis-based laboratory test performed to determine the concentrations of globulin proteins in the urine. 